\title{
The Born-Global Phenomenon in Creative Industries: the Case of Lithuanian Animation Industry
}

\author{
Tomas Mitkus ${ }^{1}$, Dimitrios I. Maditinos ${ }^{2}$ \\ ${ }^{1}$ Department of International Economics and Business Management, Faculty of Business Management, \\ Vilnius Gediminas Technical University, Vilnius, Lithuania \\ ${ }^{2}$ Business Administration department, Eastern Macedonia \& Thrace Institute of Technology, Kavala, Greece \\ E-mails:'tomas.mitkus@vgtu.lt; ${ }^{2}$ dmadi@teiemt.gr
}

Received 19 February 2017; accepted 07 April 2017

\begin{abstract}
The born-global phenomenon has been studied for over a two decades, but theory and practice are still evolving, therefore understanding how the phenomenon operates in different countries and industries is crucial. This paper aims to contribute to a better understanding of the born-global phenomenon in context of creative industries. A literature review was conducted in order to identify the nature of creative profile enterprises and international process characteristics in creative industries. Authors conducted a quantitative questionnaire with seventeen enterprises from Lithuanian animation industry. Drawing from empirical evidence, it was found that the born-globals perceive internationalization primary as a means to increase the scope of creative projects, and only then as a way to increase income. Findings as well have shown that most of Lithuanian animation studios are born-global as they started international operations within three years from enterprises' establishment.
\end{abstract}

Keywords: born-global, animation industry, creative industries, internationalization, film industry, management.

JEL Classification: M16, F23, L82.

Conference topic: Internationalization Processes: Contemporary Challenges.

\section{Introduction}

The way we perceive creative industries in the last few decades changed dramatically. If in the 1990s cultural entrepreneurs were mostly associated with activities that could be executed only because it is funded by public support (Mitkus 2011; Mitkus, Nedzinskaite-Mitke 2016), today this creative economic sector is on a spotlight as potential economic powerhouse. The shift in the way government bodies perceive creative industries happened because today it is recognised that creative sector demonstrates incredible growth, efficiency and stability (even in economic crisis), as well stimulating innovation in more traditional industries that are in need of a creative solutions, not to mention high resistance to robotization (TERA Consultants 2010; DCMS 1998, 2001; Blair et al. 2001; Hotho, Champion 2011; De Propris 2013; Goede, Louisa 2012; Daubaraite, Startiene 2013; and others).

But as most key research reports conducted by EU point out - creative industries are still a largely untapped resource (EC 2012; ESTEP 2016; Creative Europe 2009). And this issue will continue to surface for at least another decade because it is not enough to recognise that creative sectors have an unfulfilled potential in the continent. There is a recognised need to implement support policy tools that would assure a systematic growth and development of creative industries. Consequently one can safely generalize that most of these policies today are experimental. Witch by itself is not a problem - experimental support tools simply means the methodology is still under development.

Therefore issue lies not within experimentation, but with the lack of research on the topic. Or, in other words, if any national or international policy is formulated without the backing of research it can lead to the waste of time, money and other type of resources on poorly targeted, ill-conceived approaches (EC 2012). Therefore, a key and primary element to achieve goals set in Creative Europe (2009) and Europe 2020 (2010) strategies is to understand how creative industries function.

Strong, smart, sustainable and developed creative industries, as a holistic concept, means that creative profile enterprises should be able, with relative ease, expand their activities across national and EU borders and be competitive on a global scale. But as EENC report (2013) notice government bodies executing public support that supposed to increase creative industries export pursue their goals with little national policy coordination. Or, in other words, most

(C) 2017 T. Mitkus, D. I. Maditinos. Published by VGTU Press. This is an open-access article distributed under the terms of the Creative Commons Attribution (CC BY 4.0) License, which permits unrestricted use, distribution, and reproduction in any medium, provided the original author and source are credited. 
of national public support measures for creative industries in EU act independently, and not in coherence with other institutions. Not to mention that, according to the same report, most national strategies lack attention paid to the importance of creative industries export and internationalization process.

The rising awareness of the phenomenon of the born-global enterprises in creative industries forces to re-examine export and internationalization support mechanisms because this phenomenon may require a different spectrum of business support policy tools from those developed for more traditionally structured companies. This is specifically important because smaller and younger enterprises are disadvantaged in terms of access to bank credit (European Competitiveness Report 2014).

Authors of this paper do not aim to introduce an additional theoretical explanation to the phenomenon of bornglobals; rather we aim to analyse internationalization process of creative profile enterprises. More specifically, the paper focuses on the factors that in any matter effect internationalization process of "born-global" enterprises in creative industries. And such insights can be used to inform policymakers how to develop most effective schemes that promote development and growth of creative profile enterprises.

This paper is structured as follows: authors firstly will analyse various previous definitions and characteristics of born-global phenomenon and then will evaluate if there is any unique elements that could influence internationalization process for creative profile born-globals enterprises. Secondly, empirical research methodology and the collected data through questionnaire will be presented. This paper will present and discuss unique properties that born-globals in creative industries behold, also develop a number of propositions to support growth and development for creative profile enterprises. Authors will conclude with a discussion of how the born-globals compares to other creative-profile enterprises in creative industries.

\section{Literature review}

Starting the 1990s born-global companies have raised interest among researchers (Knight, Cavusgil 1996; Madsen, Servais 1997; Oviatt, McDougall 1994; Rennie 1993; Moen, Servais 2002), although this phenomenon has been reported in business press since the 1980s (Oviatt, McDougall 1994). At this point one can safely say that the research on international and global marketing has contributed sufficiently to our understanding of the marketing strategies of large global companies (Gabrielsson, Kirpalani 2004), still relatively little is known about born-global companies (Gabrielsson et al. 2008) and only few studies are related to analysis of the phenomenon in creative industries field (Montgomery, Potts 2009). Therefore, it seems necessary to study the creative profile enterprises and their reasons to seek or avoid becoming born-global and how early internationalization effects their growth. Especially in context of EU declared strategic goal to achieve smart, sustainable and inclusive growth in near future.

Reports on the appearance of born-globals all around the globe indicate that it is a phenomenon that needs to be understood. But as Gabrielsson et al. (2008) point out even after decade of research on born-global there is still a lacking of patterns that could provide information what happens to born-globals after their initial phase. Therefore, although the phenomenon appears to be relatively universal (OECD 1997; Simon 1996) the obstacle that prevents researchers' from establishing clear patterns is due to the fact that born-global companies originate from different nations, different industries and with different business cultures and traditions. Therefore as Hashai and Almor (2004) noted, there is no clear definition of the phenomenon in literature and despite academic investigation phenomenon remains under-explained (Weerawardena et al. 2007).

Thus, the vast variety of the born-global definitions and characteristics used in previous studies raises a natural problem of comparability of the results with each other. The scholars studying the born-global companies are in agreement that these enterprises usually possess the following characteristics:

- Despite the scarce resources that characterize most new enterprises, born-globals initiate internationalization process relatively soon - the timeframe from enterprise establishment to initial foreign market entry is often 3 years or less (Autio et al. 2000; McDougall, Oviatt 2000; OECD 1997; Rennie 1993);

- Management views the world as its marketplace from the outset of the enterprise's establishment (Knight, Cavusgil 1996);

- The amount of turnover derived from international operations should be no less than 25 percent (Knight, Cavusgil 1996; Madsen et al. 2000; Moen 2002).

- Enterprises usually apply innovative solution to produce unique product or process (Knight, Cavusgil 1996; Bell 1995).

It is worth mentioning that the relatively small size of typical young born-global enterprises appears to give them tactical flexibility that results in a strong competitive edge. Therefore, in some cases in spite of small size and inexperience in international transactions, high value-adding enterprises can outperform their larger, more resourceful counterparts in foreign markets (Knight, Cavusgil 1996). These successful small born-global enterprises try to build their advantage around innovations and therefore demonstrate a very adaptive performance in highly competitive or challenging environments (Nelson, Winter 1982; González-Benito et al. 2016).

Of course we must also mention that there is some variations in literature about characteristics of born-global. Some scholars argue that born-global companies should be considered only if they start international operations within 
their first year (Oviatt, McDougall 1994; McAuley 1999), while others put the timeframe up to five or even six years (Cavusgil, Zou 1994; Zahra et al. 2000). Luostarinen and Gabrielsson (2006) argue that companies should be labelled born-global only if their income from international business operations is over $50 \%$. And some scholars use small technology-oriented companies as census when defining the phenomenon (Bell 1995; Knight, Cavusgil 1996).

However, authors believe that criterion of exports ratio (or any international operations) is flawed. As Gabrielsson et al. (2008: 387) noted this aspect is greatly affected by enterprise's “country of origin, and economy, the country's neighbour markets, and other factors such as the type of industry". European Competitiveness Report (2014: 75) identifies the factors that influence internationalization decisions in enterprises as "external factors" which consist of "home country characteristics such as export promotion programmes, cost and time involved in exporting, and transport costs; and host-country characteristics such as tariffs, regulations, political risk factors, and geographical and cultural distance.". These external factors may have a strong influence in creative industries for a young company, especially in internationalization process. Gerschewski et al. (2015) argue that external factors and successful internationalisation are positively related and can be more important than firm-specific advantages. Although, as Montgomery and Potts (2009) point out, "creative industry firms, even small ones, are often born-global: whether in production, markets or both".

For the purpose of this paper, it is enough to conclude that born-globals from the very establishment of enterprise pursue a vision of becoming global despite the scarce managerial and financial resources. This kind of enterprises usually possesses some sort of unique technology or design, innovative product or service, or simply have globally required and relatively rare skill or specialized competence that is a foundation of their international competitiveness.

At this point scholars agree that born-globals phenomena is wide-spread and that these small and medium sized enterprises that are aggressively looking for a ways to start international operations are by all account beneficial for national economy. And as Knight and Cavusgil (1996: 24) point out, once the nature and success factors of the bornglobals are reasonably well understood, research that explores appropriate public policy needs to be pursued.

The contribution of this article is that it identifies proportion of the phenomenon in Lithuanian animation industry (as integral part of creative industries) and what are the key reasons and motivation to start internationalization process relatively early in creative profile enterprises life-pan. But, before moving towards analysing data collected from the questionnaire, there is a need to define creative industries and unique properties that this economic sector beholds.

First and most important aspect of the concept of creative industries is that it is heterogeneous. Or, in other words, creative industries - the group of very different industries that produce service or product that society considers as required considerable amount of creativity. Therefore, naturally, the key problem of this concept is that these segments often have very little in common. Thus, this aspect of the creative industries extremely complicates any culture related public support policy making and its implementation.

Therefore, when defining creative industries term, although created as a way to group all industries that employs creativity as a key aspect when producing product or service, it is paramount to perceive every industry (film, animation, video games, architecture, publishing, etc.) as individual and distinct community of creative profile enterprises. In fact, for professionals working in creative industries the concept of creative industries are not always clear or important because, for example, theatre, video games and film industries have more things that separate them than unite. And the labourers identify themselves primarily with the industry (segment) of theirs profession rather than with the general concept of creative industries (Mitkus 2016). In this paper the term of creative industries will be defined as group of individual industries that have very limited intertwine attributes. Therefore, any generalization about creative industries presented in this paper should be treated with caution and adequate adaptation to particular industry is required.

When analysing internationalization in creative industries there is a necessity to explore and clearly define the complexity of the process. This is because for enterprises in creative industries, internationalisation is not always associated with export. Internationalization process in creative industries, excluding export, can be broken down to four types: (a) foreign creative project execution in the local country, (b) outsourcing (to foreign countries), (c) (international) co-production, and (d) international company (Table 1). And because all segments of creative industries use project-based form, internationalization (international coproduction and outsourcing) of cultural product makes sense economically and creatively.

It happened mainly due to the digitalization revolution that truly opened unparalleled possibilities for most segments of the creative industries. And it is very important to notice that digital innovations not only forever changed the way modern cultural products are created, but also distributed. Thus, today there are many technological tools and platforms that allow not only effective global communication, but as well real-time cooperation in project execution between team members residing in different geographical locations. Therefore, digitalization is a great factor that allows creative industries to demonstrate such a strong participation in global markets of creative products and services. Although, it is important to notice that digitalisation brought some challenges that need to be solved in order to reach the potential of creative industries (Creative Europe 2009).

Today there are two main factors that infuse internationalization process in the creative industries: (1) creative enterprises in developed economies that are looking for economically sound outsourcing possibilities; and (2) national and international support schemes that are available exclusively for internationally co-produced creative projects. And 
these two factors are greatly responsible for the vast number of born-globals in creative industries, especially among enterprises that were established in the $21^{\text {st }}$ century.

Table 1. Internationalization typology in creative industries and its description (Source: authors)

\begin{tabular}{l|l}
\hline $\begin{array}{l}\text { Internationalization types } \\
\text { in creative industries }\end{array}$ & \multicolumn{1}{c}{ Definition } \\
\hline $\begin{array}{l}\text { Foreign creative project } \\
\text { execution in the local } \\
\text { country }\end{array}$ & $\begin{array}{l}\text { This operation type describes the execution of a creative project by local firms that provides partic- } \\
\text { ular service. This is by far the most popular type of international operations in creative industries. } \\
\text { Many countries in EU have indirect public support subsidies to attract foreign creative projects to } \\
\text { their countries (Lorenzen 2007; Wright 2006). These tax schemes can be found in film, animation } \\
\text { and video games industries (Palmer, Davoudi 2012). But in some countries tax incentives are also } \\
\text { applied in theater, music and publishing industries (Rossmartin 2016; KEA 2007). }\end{array}$ \\
\hline $\begin{array}{l}\text { Outsourcing } \\
\text { (to foreign countries) }\end{array}$ & $\begin{array}{l}\text { This operation type refers to the transfer of particular part of creative project to companies that are } \\
\text { resident in foreign countries. Because in creative industries the work that is done in early stage of } \\
\text { creative project is considerate to be the most innovative and creative, it is mostly late production } \\
\text { work that is transmitted to other companies (Yoon 2015). Lorenzen (2007) argues that the most im- } \\
\text { portant factor that determines the choice where to outsource is attractiveness of financial incentive } \\
\text { mechanism. }\end{array}$ \\
\hline $\begin{array}{l}\text { (International) } \\
\text { co-production }\end{array}$ & $\begin{array}{l}\text { This operation type describes two or more producing companies (from different countries) that } \\
\text { joined to execute a creative project. The main concept of the term is that companies in the copro- } \\
\text { duction have rights to a share of the profit that cultural product will produce. This type of the inter- } \\
\text { nationalization in creative industries in EU is promoted at international and national levels (Crea- } \\
\text { tive Europe 2009). }\end{array}$ \\
\hline International company & $\begin{array}{l}\text { The term describes an organization that has offices in two or more countries. Since the vast major- } \\
\text { ity of creative enterprises belong to category of small or medium-sized companies, this phenome- } \\
\text { non is quite rare in the creative industries. Creative profile enterprises usually initiate this interna- } \\
\text { tionalization process in order to gain access to a wider talent source (Lorenzen 2007). }\end{array}$ \\
\hline
\end{tabular}

The reality is that creative profile enterprises compete in hash conditions. Firstly, because of digitalisation today every company have to battle for creative service clients and cultural product users in a truly global market. And in meantime, have to face challenges of market fragmentation, intellectual property piracy and difficulties accessing financing (Dossi 2016). Therefore it is natural that Creative Europe programme (Creative Europe 2009) is focusing on developing tools that support international operations (export and co-production). It is important to notice that European long-term cultural policy strategy to develop globally competitive creative industries should also contribute to lessen dependence on public subsidies. Today the latter is still the dominant form of income in the creative sector.

Internationalisation seems to be not an attractive prospective for many enterprises in the creative industries. Despite the advantages of starting international operations and the risks of trying to avoid challenges brought by globalisation in the industry, many of European creative profile enterprises remain focused on being a local market players (EC 2007). Fitjar and Jøsendal (2016: 29) argue that, although international distribution of cultural product is relatively easy, for a creative profile enterprise to achieve successful internationalisation is difficult because products can be highly dependent on culturally-specific tastes and expectations of foreign customers. Thus, this imposes additional demands for successful entry to foreign market. Fillis (2004) noticed that creative profile enterprises being mostly small organisations produce very limited income from international operations. This situation is partly based on a factor that creative profile enterprises are making their decisions by balancing artistic and economic logic.

Eikhof and Haunschild (2007: 526) propose "economic logic" and "artistic logic" terms to explain phenomena when creative profile enterprises will choose to ignore economic benefits and/or take financial risks only to execute uncompromised creative vision. The economic logic of practice was characterised as explicit market orientation where financial benefits or profit are principal wanted outcome. By contrast, the artistic logic of practice is marked by the desire to produce art for art's sake. In creative industries both of these logics need to reach the equilibrium in order that creative profile enterprise could function successfully.

As Davenport (2006: 253) points out creative profile enterprises try to balance two principal objectives - earn an income and create products that they are passionate about. Furthermore they "have no desire to increase turnover or company size". Banks et al. (2002: 262) supports that notion and states that some enterprises are tended to prioritise "staying small" to help maintain creativity. Thus, any theoretical constructs of born-globals in creative industries must account that at any level creative profile enterprise may decide to forfeit economically valuable operation in favour for operation that promises bigger creative reward, were the later promises considerably less income.

\footnotetext{
${ }^{1}$ In this paper ,public support“ term will be used as national government's support for cultural activities by means of direct (e.g. subsidies, grants and awards) and indirect subsidies (tax expenditure), unless specified otherwise.
} 
A second somewhat unique characteristic of creative industries is that all its segments conduct their work in project-based form. Therefore internationalization operations in this economic sector, especially when the case is of a relatively bigger scale creative project, co-production and/or outsourcing are not uncommon. Furthermore, the factor that creative industries today is entirely project-based has influenced a division where on one side there are creative service providing companies, and on the other side there are artistic competency companies. Thus, these two types reach for internationalisation in completely different way.

Authors argue that there are some unique properties that born-globals in creative industries have. And these properties need to be taken into account when forming public support policy, especially the one that promotes internationalization process in creative industries. Companies that are planning to become global in creative industries from the very begging are more likely to work out the kinks to achieve harmony between economic and artistic logics. Thus, born-globals are more likely to seek to become economy independent from public support, and use the latter only to increase they competitiveness in the global market. Authors anticipate that if policy-makers would implement policy mechanisms that would heavily support creative profile enterprises to start international operations from the very start, which would effectively help to achieve goal of creative industries as economic powerhouse. Therefore, authors hypothesize that:

H1. Born-globals are dominant type in creative industries.

H2. Internationalisation process of born-globals in creative industries is greatly motivated by artistic logic.

H3. Born-globals in creative industries are less dependent on public subsidies.

\section{Empirical study}

In order to find patterns of internationalization process in creative profile enterprises, an empirical case study was conducted in 2017 January. The research was done in Lithuanian enterprises working in animation industry with seventeen respondents. The firms investigated had to meet the following three criteria in order to be included in the study:

- They need to be registered as juridical body in Lithuania;

- They need to demonstrate evidence publicly that company has competence to produce or execute cinematographic animation project;

- They should be independent firms.

The first step in the study was to compile a list of animation firms using partial lists available in government agencies, industry associations, specialized institutes, etc. The authors identified 26 animation studios in Lithuania that met the criteria above. Out of those 26 studios 2 studios was unreachable (all provided contact details in public databases were invalid), and 7 studios verbally informed authors that they refuse to participate in the research for various reasons. Therefore seventeen animation studios were investigated in this research $(71 \%$ of active animation industry in Lithuania).

The second criteria of selecting firms for research was formulated to remove companies that have animation departments but specialises in interactive projects (video games, apps and etc.). This choice was made because distribution of interactive creative product, factor that influences studio growth (education, direct and indirect state finance support system, etc.) and internationalization process, is severely different and cannot be adequately compared in many aspects. Thus, although video game industry heavily intertwine with animation industry, even more so than with film industry, but on the micro level animation and video games industries are affected by very different factors, therefore collected data from video games firms would greatly distort the findings.

A letter was sent by e-mail to all identified 24 animation firms inviting them to participate in this study. The letter emphasized the relevance of the study to collect data about the industry and its potential impact on public policymakers. Respondents were promised a summary of the study's results. A structured questionnaire with 46 questions and one extra section for comment at the end was posted in the specific internet platform. The questions were formulated so they would be incoherence with EU Europe 2020 strategy (2010), Creative Europe programme goals (2009), Lithuanian Republic Ministry of Culture Policy Guideline (2007) and Lithuanian Creative Industry Policy Guidelines for 2016-2020 timeframe (2015). The main objective of the questionnaire was for a first time in modern Lithuanian history to gather all-round information about animation industry. However, this paper only analyses collected data related to the industry's internationalization process. Thus, other collected data about preferred animation technique, artistic achievements in national or international levels, innovation processes and evaluation of national academic level and so on will not be addressed in this paper.

In addressing this objective, the research design attempted to collect data, as mention before, to gather all-rounded information about how many animation companies started internationalization process. Specifically, how soon they started international operations, what motivated (or would motivate) them and what challenges and rewords they see when executing any type of international operations. 


\section{Findings}

Collected data from conducted questionnaire revealed that $65 \%$ of Lithuanian animation studios at some point in their lifetime executed international operations (Fig. 1). And $82 \%$ of enterprises that executed international operations are born-global ( $53 \%$ of all respondents). One animation studio started international operations in its $4^{\text {th }}$ year, therefore in this paper this organisation is not considered as born-global.
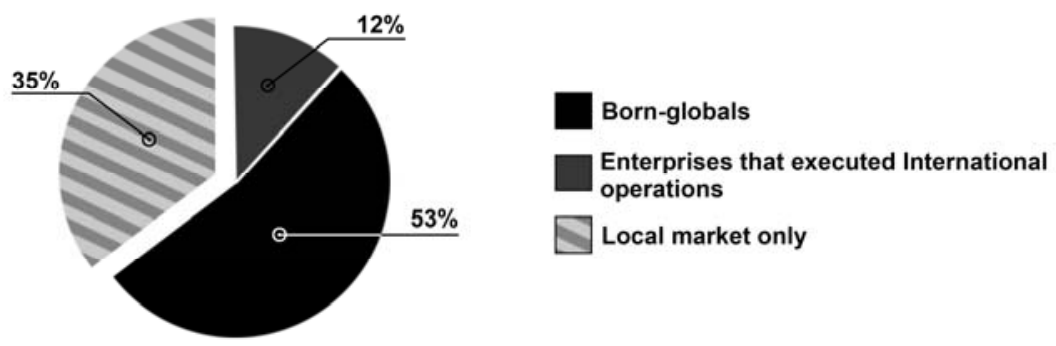

Fig. 1. Proportion of born-globals in Lithuanian animation industry (Source: authors)

Of the 17 respondents, $76.5 \%$ indicated that their studio have at least once delegated their representative to international industry event such as "Annecy International Animated Film Festival and Market" or "Cartoon Forum". Thus, even those studios that did not yet executed any international operations are investing in international networking and understanding of global trends in the industry. As well respondents were given single-answer Likert scale question, about how strongly they agree with statement that "participating in international industry events is vital to gather knowledge and skills needed to produce high quality animation project". 53\% of respondents indicated that they "strongly agree"; $24 \%$ of respondents indicated that they "more agree that disagree"; $12 \%$ of respondents stated that they "noir agree, noir disagree"; and last two answers on Likert scale ("more disagree, that agree" and "strongly disagree") both gathered $5.5 \%$ responses.

Figure 2 shows how respondents reacted to a multiple answer question "What factors would be THE MOST stimulating to start international operations to company that you represent". 59\% of respondents indicated that they would be motivated to start international operations if that would help to produce creative project of a bigger scale. Other answers like "possibility to generate more income" and "public support that would reduce financial risk of the firm" each answer gathered $41 \%$ of respondents' responses and "the limitations in local market" was considered as motivation to start international operations only by $18 \%$ of respondents.

Motivation to start international operations to produce creative project of a bigger scale becomes indicated by $89 \%$ of respondents if considering just responds of born-globals. Possibility to generate more income somewhat increases among born-globals to $44 \%$ and possible limitation in local market is important for $22 \%$ of respondents. However, public support factors become considerably less important for born-globals as only $22 \%$ of respondents from born-globals indicated it.

Respondents were asked to identify what percentage of their income is made out public support in the last 5 years. Question was formed as single answer question with five different possible answers to choose from - "studio do not have project that would be partly covered by public support", "up to $25 \%$ of studio income have come from public support", "from $25 \%$ to $50 \%$ (...)", "from $50 \%$ to $75 \%(\ldots)$ ", and "from $75 \%$ to $100 \%$ (...)". Curiously, no clear patterns could be established between companies that are born-globals, companies that executed international operations in their life-span and companies that work in local market only.



Fig. 2. Motivators to start internationalization for animation companies (Source: authors)

Yet there is a division between born-globals where on one side there is animation studios that do not produce any project that would be partly finance with public support (1/3 of all born-globals) or this type of support would be up to $25 \%$ (1/3 of all born-globals), and on other side animation studios where this type of support would be from $50 \%$ to $75 \%$ (1/3 of all born-globals). Somewhat similar proportions are among local market orientated animation studios - 
$50 \%$ of respondents indicated that their do not produce any project that would be partly financed with public support, and the rest are equally distributed (16.6\% each) between answers "up to $25 \%$ ", "from $25 \%$ to $50 \%$ " and "from $50 \%$ to $75 \%$ ".

Finally, when asked to evaluate their company internationalization intensity by choosing one of three answers (Fig. 3) "Studio is very international - not less than 50\% of all animation projects is done with international partners", "Studio is international, but less than $50 \%$ of all animation projects are done with international partners" and "Studio do not have any international operations". Excluding local market only participants (35\% of respondents) the division is that $45 \%$ is very international as appose to $20 \%$ of respondents that indicated that they are somewhat international.

Among born-globals $67 \%$ of respondents indicated that their belong in "not less than $50 \%$ of all animation projects are done with international partners" group as opposed to "less than $50 \%(\ldots)$ ". All animation companies that at least once conducted international operations, but was not identified as born-globals stated that their intensity of internationalization is less than 50\%. Evidences suggest that the born-globals are much more active in international market. It could be argued that born-globals perceive international market (as appose to local market) as they key source of income and creative fulfillment. While international but non born-global animation companies most likely had few instances when there were favorable situation for international coproduction or cultural product export, but companies themselves do not actively pursue internationalization as a continuous status. However, additional data is needed to support this premise.

\section{Discussion}

The study shows that born-globals are dominant type of enterprises in Lithuanian animation industry. Thus, this data supports the first hypothesis. In addition, the fact that $3 / 4$ of respondents indicated that their companies participate in international industry events that act as platform to form social network (e.g. "Annecy International Animated Film Festival and Market" or "Cartoon Forum") suggests that internationalisation status of the company is generally pursued in the industry. Furthermore, because participating in these industry events requires considerable financial investment it shows that animation studios perceive these events as necessary investment into the studio future. This premise is supported with the evidence that shows that more than half of industry in this study "strongly agrees" and a quarter "more agree that disagree" with the statement that participating in international industry events is vital to produce high quality animation project suggests that market is understood as truly global phenomena. These findings also support Montgomery and Potts (2009) statement that enterprises in creative industries, even small ones, are often born-global.

As Figure 2 shows internationalization process in creative industries is highly motivated by artistic logic. Or to be more precise the strongest stimulus for an animation company to start international operations lies in the possibility to enhance scale of the creative project. In compare, desire to increase economic income is considerably less motivational. This is even more so for born-globals. Thus, this data supports the second hypothesis.

In addition, evidence suggests that creative profile enterprises may self-impose restrictions on their growth because they are not entrepreneurs in the sense that the term is commonly understood. Canavan et al. (2013) argue that some companies in creative industries may choose to achieve growth through developing reputations for creating artistic masterpieces which, in return, forms international fame and prestige. Therefore studios that employ this strategy look for clients, partners and employees that are not only in harmony with their artistic and economic logic stance, but appreciate their artistic style and/or vision. Thus, the lack of human capital management skills could greatly affect how effectively organisation can obtain growth (Zukauskas et al. 2015). Although, as findings suggest, this is not always the case as some enterprises focus to provide creative services and develop their company to increase competitiveness based on market demand, not on artistic needs of the company. These results are consistent with theoretical propositions and empirical findings in the literature (Davenport 2006; Eikhof, Haunschild 2007; Banks et al. 2002).

The third hypothesis was not supported empirically. As previously mentioned, there could not be established a clear pattern in regards of public support and internationalization. This suggest that the structure of hypothesis was constructed incorrectly because the pattern may lie not in the factor of internationality as a phenomenon, or born-global for that matter, but in development strategy that creative profile company chose to peruse. It is possible, that most of creative profile studios early make a decision about which logic - economic or artistic - will be dominant in their strategic vision. Enterprises that chose pro economic logic specialise in providing commercial animation services. While on other side of this construct there is a pro artistic animation companies that focus on developing their own intellectual property. Regrettably, this study could not provide any evidence on this matter, therefore future studies is required to prove revised hypothesis. However, the new hypothesis, if empirically supported, would be consistent with theoretical propositions and empirical findings in the literature (Davenport 2006; Eikhof, Haunschild 2007; Banks et al. 2002).

It is interesting to note that empirical evidence suggests that the born-globals, no matter which company development strategy they will peruse (artistic or economic), will be more proactive and determent. While the non-bornglobals, although, are open to consider international operations, but would act on them only if the circumstances are favourable (e.g. financial risk is greatly minimised by the public support). Therefore, it seems that despite the factor that born-globals possess very limited resources at the time of establishment they are more likely to generate income 
rather than relay just on public support. This sequentially means that born-globals are more likely to achieve goals that are set by national and international strategies in order to develop strong, smart and sustainable creative industries. However, creative profile enterprises produce value not only in economic matter, but in cultural as well, therefore not all investments in to creative industries development should be measured in economic value.

\section{Conclusions}

Although, born-globals phenomenon is studied for more than two decades it is still under-explained and it is only started to assemble empirical data about the phenomena in creative industries. And in the context of today's international interest towards systematic development of creative sector this type of research become critical. Furthermore, with the rise of small and medium creative profile enterprises that see global market as its playground, tools that would help to lessen born-globals' risk are truly needed. Thus, cultural policy priorities and in extend public support (direct and indirect) should not be perceived as a tool just to support artist, but should be used to stimulate creative industry and the market.

Theoretical framework and empirical evidence in the literature support the correlation between internationalization, innovation and the overall quality of creative product or service (EC 2012; ESTEP 2016; Creative Europe 2009; TERA Consultants 2010; DCMS 1998, 2001; and others). Therefore, it is important to develop the public support tools that stimulate company's entrepreneurship. And evidence suggests that born-globals are embodiment of the concept of creative industries.

Clearly, additional research is needed on the born-global phenomenon, especially in relation to the creative industries. As a first step, a framework for studying creative profile born-global firms should be developed. This theoretical framework should account for unique characteristics that creative industries behold. In addition, both general and case study based research of the internationalisation promotion and support mechanisms within creative industries are required.

This study has important implications to both theory and cultural policy-makers. First, it shows that born-global phenomena is dominant among creative profile enterprises. Second, it provides empirical evidence that possibility of conducting bigger scale creative projects is the most stimulating motivator to start international operations. Thus, enterprises may see internationalisation primary as a source to enhance prestige rather than desire to increase turnover. Finally, evidences suggest that firms in creative industries should be attributed to one of two groups - "pro economic" or "pro-artistic". This means that policy-makers need to implement support tools not only specific to each creative segment, but to a specific group as well.

Nevertheless, it is important to note several limitations of this study. The main two regards the small sample size and applications of results to the rest of creative industries segments. Although, 17 animation studios represent $71 \%$ of active animation industry in Lithuania, the sample is still small to define conclusive patterns. Furthermore, factors of the country's origin and economic, political environment, even the quality of education or traditions in the local industry, not to mention other external factors that could influence how creative profile enterprise will perceive internationalization and its benefits and challenges. Therefore, since the study was built based on a survey with Lithuanian animation studios, researchers and policy-makers should be cautious when generalizing to other countries and/or segments. Authors, thus, suggest that this study would be expanded to other countries and creative segments as a way to validate universality of the results.

\section{References}

Autio, E.; Sapienza, H. J.; Almeida, J. G. 2000. Effects of age at entry, knowledge intensity, and imitability on international growth, Academy of Management Journal 43: 909-924. https://doi.org/10.2307/1556419

Banks, M.; Calvey, D.; Owen, J.; Russell, D. 2002. Where the art is: defining and managing creativity in new media SMEs, Creativity and Innovation Management 11(4): 255-264. https://doi.org/10.1111/1467-8691.00257

Bell, J. 1995. The internationalisation of small computer software firms: a further challenge to "stage" theories, European Journal of Marketing 29(8): 60-75. https://doi.org/10.1108/03090569510097556

Blair, H.; Grey, S.; Randle, K. 2001. Working in film. Employment in a project based industry, Personnel Review 30(2): 170-185. https://doi.org/10.1108/00483480110380334

Canavan, D.; Scott, p. S.; Mangematin, V. 2013. Creative professional service firms: aligning strategy and talent, Journal of Business Strategy 34(3): 24-32. https://doi.org/10.1108/JBS-10-2012-0058

Cavusgil, S. T.; Zou, S. 1994. Marketing strategy-performance relationship: an investigation of the empirical link in export market ventures, Journal of Marketing 58: 1-21. https://doi.org/10.2307/1252247

Creative Europe. 2009. Europos Parlamento ir Tarybos Reglamentas (ES) Nr. 1295/2013. 2013 m. gruodžio 11 d. kuriuo sukuriama programa „Kūrybiška Europa“ (2014-2020 m.) ir panaikinami sprendimai Nr. 1718/2006/EB, Nr. 1855/2006/EB ir Nr. 1041/2009/EB.

Daubaraite, U.; Startiene, G. 2013. Creative industries impact on national economy in regard to subsectors, Procedia - Social and Behavioral Sciences 213: 129-134. https://doi.org/10.1016/j.sbspro.2015.11.415

Davenport, J. 2006. UK film companies: project-based organizations lacking entrepreneurship and innovativeness? Creativity and Innovation Management 15(3): 250-257. https://doi.org/10.1111/j.1467-8691.2006.00394.x 
DCMS. 1998. A new cultural framework. London: HMSO.

DCMS. 2001. Creative industries mapping document 2001. London: Department of Culture, Media and Sport.

De Propris, L. 2013. How are the creative industries weathering the crisis? Cambridge Journal of Regions, Economy and Society 6: 2335. https://doi.org/10.1093/cjres/rss025

Dossi, S. 2016. The creative Europe programme. European Implementation Assessment. European Parliamentary Research Service.

EC. 2007. Enterprise and Industry Directorate General, promotion of SME competitiveness, Final Report of the Expert Group on Supporting the internationalization of SMEs. Brussels: European Commission.

EC. 2012. Communication from the Commission to the European Parliament, the Council, the European Economical Social Committee and the Committee of the Regions - Promoting cultural and creative sectors for growth and jobs in the EU. Brussels: COM 537 final. Available from Internet: http://ec.europa.eu/culture/our-policy-development/documents/com537_en.pdf

EENC. 2013. Mapping of Cultural and Creative Industry Export and Internationalisation Strategies in EU Member States. European expert network on culture, February 2013.

Eikhof, D. R.; Haunschild, A. 2007. For art's sake! Artistic and economic logics in creative production, Journal of Organizational Behavior 28: 523-538. https://doi.org/10.1002/job.462

ESTEP. 2016. 2007-2013 metu Europos Sajungos struktūrinès paramos poveikio kultūrai vertinimas. Galutine ataskaita. 2016 m. spalio $13 d$. Vilnius: ESTEP.

Europe 2020. 2010. COMMUNICATION FROM THE COMMISSION EUROPE 2020 A strategy for smart, sustainable and inclusive growth. Brussels: European Commission.

European Competitiveness Report. 2014. Helping Firms Grow. Luxemburg: European Commission.

Fillis, I. 2004. The Internationalizing Smaller Craft Firm, International Small Business Journal 22(1): 57-82. https://doi.org/10.1177/0266242604039481

Fitjar, R. D.; Jøsendal, K. 2016. Hooked up to the international artistic community: external linkages, absorptive capacity and exporting by small creative firms, Creative Industries Journal 9(1): 29-46. https://doi.org/10.1080/17510694.2016.1154654

Gabrielsson, M.; Kirpalani, V. H. M. 2004. Born globals: how to reach new business space rapidly, International Business Review 13(5): 555-571. https://doi.org/10.1016/j.ibusrev.2004.03.005

Gabrielsson, M.; Kirpalani, V. H. M.; Dimitratos, P.; Solberg, C. A.; Zucchella, A. 2008. Born globals: propositions to help advance the theory, International Business Review 17(4): 385-401. https://doi.org/10.1016/j.ibusrev.2008.02.015

Gerschewski, S.; Rose, E. L.; Lindsay, V. J. 2015. Understanding the drivers of international performance for born global firms: an integrated perspective, Journal of World Business 50: 558-575. https://doi.org/10.1016/j.jwb.2014.09.001

Goede, M.; Louisa, G. 2012. A case study of the creative zone Scharloo and Pietermaai in Curacao, International Journal of Social Economics 39 (11): 844-858. https://doi.org/10.1108/03068291211263899

González-Benito, O.; Muñoz-Gallego, P. A.; Garc ía-Zamora, E. 2016. Role of collaboration in innovation success: differences for large and small businesses, Journal of Business Economics and Management 17(4): 645-662. https://doi.org/10.3846/16111699.2013.823103

Hashai, N.; Almor, T. 2004. Gradually internationalizing "born global” firms: an oxymoron? International Business Review 13: $465-483$. https://doi.org/10.1016/j.ibusrev.2004.04.004

Hotho, S.; Champion, K. 2011. Small businesses in the new creative industries: innovation as a people management challenge, Management Decision 49(1): 29-54. https://doi.org/10.1108/00251741111094428

KEA. 2007. Tax incentives for Creative Industries Investment. Paris: French Ministry of Culture.

Knight, G. A.; Cavusgil, S. T. 1996. The born global firm: a challenge to traditional internationalization theory, in Cavusgil, S. T. (Ed.). Advances in international marketing. Vol. 8: 11-26.

Lorenzen, M. 2007. Internationalization vs. globalization of the film industry, Industry and Innovation 14(4): 349-357. https://doi.org/10.1080/13662710701543650

Luostarinen, R.; Gabrielsson, M. 2006. Globalization and marketing strategies of born globals in SMOPECs, Thunderbird International Business Review 48(6): 773-801. https://doi.org/10.1002/tie.20122

Madsen, T. K.; Rasmussen, E. S.; Servais, P. 2000. Differences and similarities between born globals and other types of exporters, Advances in International Marketing 10: 247-265. https://doi.org/10.1016/S1474-7979(00)10013-4

Madsen, T.; Servais, P. 1997. The internationalization of born globals - an evolutionary process, International Business Review 6(6): 114. https://doi.org/10.1016/S0969-5931(97)00032-2

McAuley, A. 1999. Entrepreneurial instant exporters in the Scottish arts and crafts sector, Journal of International Marketing 7(4): 67- 82.

McDougall, P. P.; Oviatt, B. M. 2000. International entrepreneurship: the intersection of two research paths, Academy of Management Journal 43(5): 902-906. https://doi.org/10.2307/1556418

Ministry of Culture policy guideline. 2007. Kürybiniu industriju skatinimo ir pletros strategija. Lietuvos Respublikos kultūros ministro 2009 m. kovo 28 d. įsakymas Nr. IV-217.

Ministry of Culture policy guideline. 2015. Kultūros ir kūrybiniu industriju politikos 2015-2020 metų plètros kryptys. Lietuvos Respublikos kultūros ministro $2015 \mathrm{~m}$. liepos $31 \mathrm{~d}$. įsakymas Nr. IV-524.

Mitkus, T. 2011. Lietuvos kino industrija XXI a.: valstybės remiamas menas ar verslas? Santalka. Filosofija. Komunikacija 19(2): 76-89. https://doi.org/10.3846/coactivity.2011.17

Mitkus, T. 2016. Internationalization process of creative industries: tendencies, problems and challenges, Forum Scientiae Oeconomia 4(4): 27-37. 
Mitkus, T.; Nedzinskaite-Mitkè, V. 2016. The impact of globalization to creative industries: the analysis of film industries of Central and Eastern Europe, Creativity studies 9(1): 64-74.

Moen, Ø. 2002. The internet and international marketing: an empirical analysis of small and medium sized Norwegian firms, Quarterly Journal of Electronic Commerce 3(1): 31-41.

Moen, Ø.; Servais, P. 2002. Born global or gradual global? Examining the export behavior of small and medium-sized enterprises, Journal of International Marketing 10(3): 49-72. https://doi.org/10.1509/jimk.10.3.49.19540

Montgomery, L.; Potts, J. 2009. Does weaker copyright mean stronger creative industries? Some lessons from China, Creative Industries Journal 1(3): 245-261. https://doi.org/10.1386/cij.1.3.245_1

Nelson, R. R.; Winter, S. G. 1982. An evolutionary theory of economic change. Cambridge: Belknap Press.

OECD. 1997. Globalization and small and medium enterprises. Paris: Organization for Economic Cooperation and Development.

Oviatt, B. M.; McDougall, P. P. 1994. Toward a theory of international new ventures, Journal of International Business Studies 25(1): 4564. https://doi.org/10.1057/palgrave.jibs. 8490193

Palmer, M.; Davoudi, S. 2012. Creative industries boosted by tax breaks. Financial Times [online], [cited 2017-02-03]. Available from Internet: https://www.ft.com/content/b71357e8-7358-11e1-9014-00144feab49a

Rennie, M. W. 1993. Global competitiveness: born global, The McKinsey Quarterly 4: 45-52.

Rossmartin. 2016. Creative Industries Tax Reliefs: at a glance [online], [cited 2017-02-03]. Available from Internet: http://www.rossmartin.co.uk/companies/running-the-business/1135-creative-industries-tax-reliefs

Simon, H. 1996. Hidden champions: lessons from 500 of the world's best unknown companies. Boston: Harvard Business School Press.

TERA Consultants. 2010. European Competitiveness Report 2010. Luxembourg: Luxembourg Office for Official Publ. of the European Communities.

Weerawardena, J.; Mort, G. S.; Liesch, P. W.; Knight, G. 2007. Conceptualizing accelerated internationalization in the born global firm: a dynamic capabilities perspective, Journal of world business 42(3): 294-306. https://doi.org/10.1016/j.jwb.2007.04.004

Wright, C. 2006. Hollywood's disappearing act: international trade remedies to bring Hollywood home, Akron Law Review 39(3): 739862.

Yoon, H. 2015. Globalization of the animation industry: multi-scalar linkages of six animation production centers, International Journal of Cultural Policy 1-18. https://doi.org/10.1080/10286632.2015.1084298

Zahra, S. A.; Ireland, R. D.; Hitt, M. 2000. International expansion by new venture firms: International diversity, mode of market entry, technological learning, and performance, Academy of Management Journal 43(5): 925-950. https://doi.org/10.2307/1556420

Zukauskas, P.; Vveinhardt, J.; Melnikas, B.; Grančay, M. 2015. Dynamics of attack actions in the mobbing strategy: the case of Lithuania, Journal of Business Economics and Management 16(4): 733-752. https://doi.org/10.3846/16111699.2015.1068840 